\title{
Autonomy and School Management in the Spanish Context
}

\section{Joaquín Gairín Sallán}

Universitat Autònoma de Barcelona - Department of Applied Pedagogy (Spain)

doi: 10.7358/ecps-2015-011-gair_joaquin.gairin@uab.cat

\section{L'AUTONOMIA E LA GESTIONE DELLA SCUOLA NEL CONTESTO SPAGNOLO}

\begin{abstract}
Processes of educational decentralisation often arise in the development of institutional autonomy. Through this, a contextualisation of education is sought as well as a greater involvement of its key players. School autonomy has been developing since 1985, when school boards were established and they had to select principals and school managers. Although legislative changes have continued to occur, there has been little progress in curricular autonomy, and the development of organisational and economic-administrative autonomy continues to be a challenge in the Spanish context. The autonomous community management model that has been set up is linked to the choice of principals for a short time. Although the Autonomous Community of Catalonia has developed a more professional proposal, including prior training and presentation of management projects, it certainly continues to be a malfunction in the education system and a cause for constant controversy. This text reviews the creation and development of the proposals that have been made on autonomy and management in the Spanish context.
\end{abstract}

Keywords: Decentralisation, Innovation, Institutional autonomy, Leadership, Management.

\section{INSTITUTIONAL AUTONOMY AS A FRAMEWORK}

Institutional autonomy, understood as the capability of an institution to take its own decisions on the organisation and development of educational activ- 
ity, has been a more or less explicit and present constant in the pedagogical debate of the last decades. It has instilled hope, channelled dreams and driven efforts, but has also been a framework in which frustration, disenchantment and disappointment have grown.

\subsection{Decentralisation and institutional autonomy}

The democratisation of societies, the need to respect local social and cultural peculiarities and the principle of fairness (non-equal distribution on the basis of existing needs) foster a change in trend in the processes of decentralisation. This marked the birth of national education systems in the 19th century and involved processes of decentralisation and de-concentration as well as an increase in institutional autonomy. The process has to adjust to another type of society (post-industrial, «third wave», or the so-called knowledge society), characterised by sociocultural and economic dynamism, the coexistence of different values and the need for high level education for citizens.

The arguments for and against the centralisation-decentralisation process are various. However, speaking of advantages and drawbacks, reasons related to efficiency and rationality continue to be propositions used opportunely by people and groups of different political persuasions. We must see the debate as an eminently political-economic one linked to socioculturalhistorical circumstances and, therefore, we must consider it as something dynamic, subject to change and the unstable result of the joining of forces that are involved in one school management or another.

These initial observations fit perfectly in the Spanish context of the 1970s. After the death of Francisco Franco in 1975 the search for a mutually agreed framework of what the State should be became necessary. The legitimate aspirations of the different nationalities found a path for development with the recognition of the Autonomous Communities and the transfer to these Communities of broad responsibilities, which would allow the structuring of their own education systems, differentiated in each territory. However, the restrictive character of the state laws and the lack of initiative on the part of our education authorities have only generated significant progress in the processes of linguistic normalisation and participation, but have meant stagnation in central issues such as educational research and school innovation. For this reason, the decentralisation processes have not significantly reinforced institutional autonomy.

From the school models presented by Marchesi and Martin (2002, pp. 349-352), the Spanish education system is based on the community model. In fact, the adoption of the institutional proposals and school pro- 
jects, defined as Educational Project, Curricular Project, regulations particular to the school, improvement Plans, etc. belong to the liberal Models and the community Model, which require a great contextualisation of education and which seek it through decentralisation and institutional autonomy processes, even if they may have a different meaning for each ideological orientation.

\subsection{Institutional autonomy as a proposal}

Institutional autonomy has always existed, whether granted by decree or not, due to the fact that it is quite impossible to control what takes place in schools. Even in highly centralised education systems with uniform proposals, different educational contexts will occur, as a direct result of the filter that institutional history and the dominant culture apply to any external influence.

The reference to school autonomy already appears in our organic laws on education. The Organic Law on the Right to Education (LODE) of 1985 is linked to the promotion and development of the school boards, the Education Law (LOCE, 2002) affects curricular autonomy and the Improvement Law (LOMCE, 2013) reinforces the powers and competencies of school management.

In any case, the greatest development has taken place in Catalonia as a result of the Education Law of Catalonia (LEC) of 2009. Previous regulations had focused on the improvement of resources or on curricular changes, but this law has an influence over the governance and organisation of schools (Maragall \& Colomé, 2013).

The LEC affects three broad interrelated fields: school autonomy, management and evaluation. Decree 102/2010 on autonomy (August 3, 2010) establishes the possibility to make co-responsibility agreements between schools and the education administration and, although in an unequal way, it regulates aspects related to management, organisation and pedagogy.

Real institutional autonomy continues to be, currently and in this context, more a discourse than an empowered and supported practice. There has been some progress in curricular autonomy (although it has often been drowned out and rendered void by administrative and organisational behaviour with standardising tendencies), but it has been little and token in the organisational, economic and representative perspectives.

The hopes that led to the belief that a new working framework could have an impact on issues such as professional development, curricular contex- 
tualisation, strengthening of innovation or on a greater and better response to the education needs of students are disappointing when we see how little advancement has been made on issues relating to the grouping of students, the flexibility of timetables, the presence of active methodologies and the generalisation of teams of teachers working in association.

Autonomy is therefore limited to the design of the curriculum, when what is important is development, and curricular management is understood to be subject to decrees, when it depends on purposes intrinsic to professional activity and, therefore, is dependent on the will of people and not so much on the interests of the administrations.

\subsection{Institutional autonomy as a reality}

Speaking about autonomy as a reality and not just words means sharing the utopia belonging to education. It is easier to conceive reforms rather than put them into practice or to implement them, although this does not mean they are unnecessary.

The Report of the first Section of the National Education Conference (CNE) of Catalonia carried out from 2001-2002 already assumed an optimistic situation (Table 1) and referenced various situations of institutional autonomy.

In any case, the basic problem is that the kind of autonomy needed is not known. Questions concerning the degree and level of autonomy are unanswered. Do we know if developed autonomy is the only possible autonomy? Is it possible to promote autonomy without making broader reforms that affect society, culture and the economy? What compensatory mechanisms are necessary to ensure that the process of autonomy in schools does not affect equality? How can we make professionalised school management compatible with the autonomous organisation of schools?, etc.

There are continuous doubts and hopes that affect spheres from administration to schools and teacher support systems. The success or failure of the institutional autonomy desired, in the qualitative sense, will depend on how these questions are addressed and resolved.

We do not deny the efforts made by school administrations in recent years. The extension of school attendance, school buildings, the training of the teaching staff, ratios, computer technology investments and so on have improved, increasing the budget of education. But all these improvements do not respond to the demands of institutional autonomy yet. The big issue, the core and fundamental matter, still has a name: commitment, financing and teaching staff. 


\begin{tabular}{|c|c|c|c|}
\hline & $\begin{array}{l}\text { ACADEMIC } \\
\text { AUTONOMY }\end{array}$ & $\begin{array}{l}\text { FINANCIAL } \\
\text { AUTONOMY }\end{array}$ & $\begin{array}{c}\text { ADMINISTRATIVE } \\
\text { AUTONOMY }\end{array}$ \\
\hline 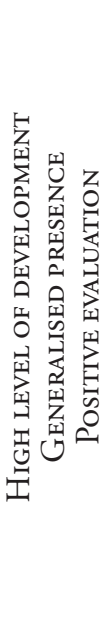 & $\begin{array}{l}\text { Procedures and decisions } \\
\text { relating to the systems, } \\
\text { methods and criteria } \\
\text { for the evaluation } \\
\text { and promotion of the student } \\
\text { body. } \\
\text { Creation of proposals } \\
\text { of content and methodologies } \\
\text { with relation } \\
\text { to the variable credits } \\
\text { of the ESO } \\
\text { secondary education system } \\
\text { and the optional materials } \\
\text { of the bachillerato further } \\
\text { education system. }\end{array}$ & $\begin{array}{l}\text { More flexible management } \\
\text { of the proposal particula } \\
\text { to the school. } \\
\text { Acceleration of the processes } \\
\text { of expense justification. } \\
\text { Insufficiency of economic } \\
\text { assignments. } \\
\text { Involvement of the AMPAs } \\
\text { (Associations of Mothers } \\
\text { and Fathers of Students) } \\
\text { in the development } \\
\text { of projects. }\end{array}$ & $\begin{array}{l}\text { Positive experience } \\
\text { of the assignment of teaching staff } \\
\text { to attached schools. } \\
\text { Possible usefulness of strategic plans } \\
\text { to improve this autonomy. }\end{array}$ \\
\hline 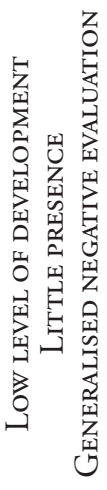 & $\begin{array}{l}\text { Individual systems of school, } \\
\text { personal and professional } \\
\text { tutoring and guidance. } \\
\text { Light modifications } \\
\text { of the organisational structure } \\
\text { of the schools. } \\
\text { Experiences of inter-institutional } \\
\text { collaboration. } \\
\text { Power to establish the weekly } \\
\text { timetable. }\end{array}$ & $\begin{array}{l}\text { Unsuitability to real expense } \\
\text { (semi-private schools). }\end{array}$ & $\begin{array}{l}\text { Competition for transfer in state } \\
\text { schools. } \\
\text { Possibility of influence } \\
\text { in the selection of teaching staff. } \\
\text { Evaluation and monitoring } \\
\text { of teaching staff. }\end{array}$ \\
\hline 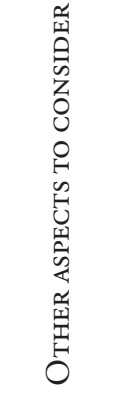 & \multicolumn{3}{|c|}{$\begin{array}{l}\text { The development of autonomy is strongly linked to possibilities of managing the teaching staff. } \\
\text { Influence of textbooks in the construction of standardised curricular proposals. } \\
\text { Inadequate practices in the use of secondments as mechanisms for assigning teachers to positions. } \\
\text { Need to review the state school management model. } \\
\text { Local bodies have collaborated in making school education more dynamic. } \\
\text { Their work on: } \\
\text { - programmes of social guarantee, prevention and control of truancy; } \\
\text { - programmes in the schools and creation of agreements stands out. } \\
\text { In some aspects there has been de-concentration rather than decentralisation. }\end{array}$} \\
\hline
\end{tabular}


The reality is that, for the time being, the current models of self-government do not seem satisfactory if we consider how poorly they have helped school improvement. In this context, to advocate the project-based management, as indicated by Bolivar (2004, p. 113), the role of the school could be reinforced as a unit for improvement. However, the main problem is still the resistance of some bureaucratic and standardising tendencies that could again hinder the restructuring of the task of schools and of teachers.

\section{SCHOOL MANAGEMENT AS PRECISION}

The proposal of school autonomy is usually accompanied by new models of leadership. School principals, for example, are in a position to make decisions, even regarding staff management (Eurydice, 2007). In any case, the OECD itself warns that educational leadership, which must be accompanied by processes of management professionalization, does not necessarily entail the development of autocratic management models.

Distributing leadership across different people and organisational structures can help to meet the challenges facing contemporary schools and improve school effectiveness. This can be done in formal ways through team structures and other bodies or more informally by developing ad hoc groups based on expertise and current needs. (Pont, Nusche, \& Moorman, 2008)

Management is not only linked with the way the school system is structured, but also with the way it functions.

School autonomy is a multi-faceted policy. Depending on the field that is emphasised - management and/or pedagogy -, and the style of leadership vertical or shared - and the mechanisms of governance - competition or cooperation - to which it is associated, one can arrive at very different practices and with implications that are also very diverse in how they affect the day-today of schools and their results. (Bonal \& Verger, 2013, p. 60)

School management in Spain, implemented with the 1985 LODE, obeys its own model characterised by choice and a provisional nature. On the one hand, school principals are chosen by the school board (where the representation of the teaching staff has great weight) and, on the other, their mandate is limited in time (four years, though they may be renewed). It obeys the proposal of the autonomous community model of functioning mentioned above, where the orientation of the school is set by the school board and the management teams are considered executors of the decisions that are made collectively. 
In this context, it is not surprising that management is not a very desirable destination for the teaching staff and that there are constant changes within it. In fact, the most recent regulations are intended to reinforce the figure of school management.

In this sense, Decree 155/2010 on management (November 2, 2010) of the Autonomous Community of Catalonia promotes the professionalization of the figure of the principal, establishes evaluation and promotion mechanisms (including salary incentives) and grants powers to principals in fields which were not under their responsibility until now, such as the selection of teaching staff and increasing the external resources for the school. It also introduces systems of accreditation of the management and a system of choice where the education administration is included. In fact, rather than going into greater depth in line with school democracy, it focuses on the professionalization of principals in the perspective of effectiveness and the emulation of private management models (Eurydice, 2007).

This greater dedication to school management and project could collide with already existing school projects, and entail a setback in the already low real autonomy of schools.

Although the decree on autonomy established that the education project of the school is the "greatest expression" of its autonomy (art. 2), sources from the Department see this project as a form of general ideology, and consider the most relevant and strategic document for the running of schools to be the project of the principals. (Bonal \& Verger, 2013, p. 68)

In fact, the reinforcement of school management actually demonstrates the tendency to decrease institutional autonomy and increase the control of external authorities. This is in line with the tendency to standardise school curricular projects or the establishment of periodic external monitoring (revalidation). This chosen option is a way of structuring the relationships between system and schools and is more based on monitoring rather than competency.

Principals and teachers compare new, different and complex situations emerging from a society which is in a constant process of transformation and serving users who are conscious of the quality of the services that they require. In this situation it is important that (Pont, Nusche, \& Moorman, 2008; Silva, 2010; Bolívar, 2012; Gómez-Dacal, 2013; Malpica, 2013): (1) educational responses take into account complex phenomena such as the rapid generation and transformation of cultural content, the extension of school attendance, the diversity of the student body, the new demands of a multicultural and knowledgeable society, the contextualisation of the curricular proposals and the assumption of training as a collective task; (2) the 
teachers attend training and improve constantly; and (3) principals adopt personal and institutional changes in their role.

The lack of development of autonomy and management in Spain (with the above-mentioned exception of the Autonomous Community of Catalonia) reduces management to an executive arm of the education policies made and, in this sense, leaves little room for personal and contextual initiatives. This circumstance explains the continuous reference to the competencies set by the education administration both in Spain and in Latin America (the works of Silva, 2010; Quiroga, 2013; and Leiva, 2014, are almost an exception) and the lack of competencies related to the practical problems of principals.

This focus conditions both the processes of selection and those of promotion and professional development of principals. Therefore, for example, the responsibilities related to cognitive, management, strategic and procedural aspects still have a strong consideration. They are aligned in this way with the activities of planning and management that constitute the basic nature of management (Antúnez, 2002 and 2013), avoiding references to analytical and conceptual thought, the orientation towards families or continued learning, which suggest to us the existence of a very technocratic management which is model focussed, based, on the application of knowledge for the management of the current situation and not for the promotion of change or greater openness to the local environment.

The strong presence of the above-mentioned management model is also evidenced when one considers the lack of personal competencies (including empathy and emotional intelligence) and of those related to the achievement of objectives and results. It would seem, in this context, that the concern of education systems is more focussed on principals performing their prescribed task rather than on achieving their own development, the development of further professionalism and the achieving of positive results for society.

\section{Possibilities AND Limitations FOR CHANGE}

The pairing of institutional centralisation-autonomy continues to represent the two extremes of education proposals that focus more on an education in service to the "State» or on service to "the education community». In any case, the tendency towards institutional autonomy is imposed when one considers the importance of responding to contextual needs and of involving the key players in the improvement of the quality of education.

In the case of Spain, development of autonomy has been an issue since 1985 , but its specification is minimal due to various ups and downs, and not 
so specified in relation to organisational and administrative-economic autonomy. Some of the difficulties that affect its development were exposed in the framework of the conference held in Rome on Educational leadership in Latin Europe. Autonomies, identities, responsibilities and reference was made to:

- Lack of specification of the frameworks and limits of autonomy.

- Real possibilities to manage the teaching staff and have academic, organisational, financial and administrative autonomy.

- Inadequate models of institutional management.

- Lack of commitment of the system and of the teaching staff to the proposal.

- Negative influence of workbooks, external regulations, etc. on the promotion of institutional responsibility.

The task to achieve the real implementation of autonomy is political, technical and ethical, and achieving it will only be possible if certain conditions are met, if foreseeable dysfunctions are limited and if the questions of society and education are asked (answered) (Table 2).

We could say that in the Spanish context the conditions have not occurred, and neither has the development of autonomy taken into account variables that could impede its development. Perhaps the most remarkable and contradictory fact is that the sense of autonomy must be promoted from general regulations that act from a standardising perspective. With regard to development, there has been little progress in the application of proposals, and they have not been accompanied by explicit commitments on the part of schools or their teaching staff.

Table 2. - Conditions and limitations of the development of institutional autonomy (Gairin, 2005, pp. 310-319).

\begin{tabular}{|c|c|}
\hline Conditions & LimitATIONS \\
\hline $\begin{array}{l}\text { - Specification of the degree of autonomy } \\
\text { (curricular, organisational, economic, ...). } \\
\text { - Commitment of all. } \\
\text { - Establishment of compensatory mechanisms. } \\
\text { - Communication between institutions. } \\
\text { - Strengthening of school projects. } \\
\text { - Teaching and management } \\
\text { professionalization. } \\
\text { - Change in the work conditions that provide } \\
\text { more means for action. } \\
\text { - Progression in the application. } \\
\text { - Pellaborative work in competition. }\end{array}$ & $\begin{array}{l}\text { - No recognition of the right to difference. } \\
\text { - Reproduction of centralising frameworks. } \\
\text { - Reproduction of pro-independence } \\
\text { frameworks. } \\
\text { - Strengthening of regulations on processes. } \\
\text { - Primacy of personal autonomy. } \\
\text { - Inexistence of control processes. } \\
\text { - Derivation from the discourse. } \\
\text { - Autonomy as an end. } \\
\text { - The modification of the equality } \\
\text { of opportunity. }\end{array}$ \\
\hline
\end{tabular}


In any case, it is worth reiterating that school autonomy is one of the education policies that, apparently, generates the most consensus in the OECD (Bonal \& Verger, 2013, p. 57). Pedagogical autonomy correlates positively with school performance in the PISA tests, and the autonomy of resource management, although it does not maintain this relationship, is also related to good results in those countries where accountability policies are more present (OECD, 2011)

Therefore, it is considered a key element of education quality:

Autonomy is an indispensable element for directing the activity of schools, it allows a more flexible relationship with the environment and facilitates the generation of education responses better adapted to their specific needs. It constitutes one of the basic conditions for achieving efficient management in education quality. (Consell Escolar de Catalunya, 2003)

The battle for autonomy is, therefore, not lost if the political will exists. Even in a slow, but firm, manner, it is essential to make progress on issues such as the selection and monitoring of teaching staff by schools or areas, greater involvement of schools in the acquisition of non-perishable materials, greater speed in bureaucratic processes, strengthening and support for innovation initiatives and others. Specifically, this means generating and broadening spaces for action, reflection, debate and exchange of experiences, as well as extending the processes of evaluation, adjustment and compensation of the inequalities that allow respect for the principle of fairness as a collateral to that of autonomy.

Advancing in this way requires specifications if we want to overcome mere statements such as those listed in Table 3.

Many of the proposals made coincide with those presented in Line 1 of the education policies of the International Forum on Education and Technology (FIET, 2014) held in Tarragona (Spain) on 25 and 26 June. Those that were made in the framework of autonomy and school management are summarised as follows:

- Autonomy as a recognised principle must take place in schools which have access to this possibility after a certain experience and abiding to a contract of commitments.

- Autonomy is justified and must serve to bring education closer to the area and its users, promoting social cohesion and the equality of opportunity.

- Autonomy is accompanied by periodical accountability actions for society.

- The promotion and development of school autonomy is supported by specific pedagogical projects assumed by the community, groups of teachers who work on them collaboratively and strong pedagogical leadership.

- The necessary management model is that of trained, community management focussed on improvement. Conceived as part of the collective pro- 
ject, it must be capable of developing distributed leadership and render the collaborative work of the teaching staff and the education community more dynamic.

- Principals must have previous initial training and permanent training related to the exercise of their role, autonomy for the configuration of the professional teams of the centre and systematic evaluation of their activity.

- The structuring and development of teams that, in a complementary manner, can respond to complex tasks currently demanded by institutional organisations and managements seems essential.

- The professional development of principals complements the previous initial training at a master's degree level with programmes of permanent development that include seminars, work groups and collaborative networks that facilitate the exchange and development of significant experiences.

Table 3. - Proposals for the development of institutional autonomy.

NEw ACTIONS
$\begin{aligned} & \text { - Differentiating actions of the Administration. } \\ & \text { - Promoting Administration-school agreements linked } \\ & \text { to school projects. }\end{aligned}$ - Enabling schools to order their own structure of functioning.
- Strengthening participation and co-responsibility of the entire
education community.


Many of the proposals presented have been debated in various forums (Bolívar, 2004; Bonal et al., 2004; Departament d'Educació, 2005). However, they must comply with the regulations prescribed.

The development of autonomy must be understood, in any case, as a means made available to schools for their own development and in order to improve the quality service that society and its citizens desire. Through this, educational and social figures must be mobilised so that they can contribute to make institutions more dynamic thanks to processes of participation that facilitate the creation of collective projects giving identity and cohesion to education communities.

Recognizing limitations, conditions and possibilities should not serve as a pretext to limit its accomplishment. In fact, we cannot assume that problems will never arise and we must consider that the strengthening of autonomous schools is always more essential if we aspire to a quality school which makes sense for, and is useful to, society.

With regard to management, it is important to highlight the importance that is being given to leadership focussed on pedagogical aspects. Whether under the name of pedagogical leadership, learning-focussed leadership or student-focussed leadership, and ignoring theoretical nuances and practical orientations, what is certain is that there is real interest in linking the activity of principals with the promotion, development and permanent improvement of innovative learning environments.

Various reports (Badia \& Martínez, 2012; Martínez, Badia, \& Jolonch, 2013) suggest that leadership has great influence on management and results, both at the micro level of school and learning environments and in larger systems. Particularly, the reports cited and developed in the framework of a collaboration between the OECD/ILE (Innovative Learning Environments project) and the Fundació Bofill (Barcelona) highlight the importance and significance of promoting processes of innovation through teachers who work collaboratively and who have relationships with the families/environment and with other schools.

Schools focusing on learning emphasize shared vision and action plans with measurable objectives which is explained through three key elements (Salavert, 2013, p. 36): (a) the leadership of the organisation that facilitates and promotes the collaborative work of the teaching staff; (b) educational leadership, focussed on curricular organisation; and (c) teaching, focusing on expectations and the evaluation that allows self-regulation.

The objectives of learning-focussed leadership are the success of each and every one of the students, the promotion of an institutional culture that promotes the learning and professional development of the teachers in that perspective, the implementation of management processes focussed on the 
quality of training and the achievement of collaboration with the environment in relation to these objectives. In this respect, the promotion and development of professional communities is considered important as a proposal and practice for achieving a common culture focussed on the priority objectives of schools (Hargreaves \& Fink, 2008; Hallinger, 2011; Fullan, 2012; MacBeath, 2012; Marsick, 2013).

The study of Martínez, Badia and Jolonch concludes in a decisive manner:

Different aspects related to leadership have been demonstrated in experiences, such as the importance of the management team and its role in the promotion of processes, but also in the generation of conditions for the emergence of collaboration and the adhesion to a shared project on the part of teachers and the rest of the community. (2013, p. 187)

\section{REFERENCES}

Antúnez, S. (2002). La acción directiva en las instituciones escolares (2n ed.). Barcelona: ICE-Horsori.

Antúnez, S. (2013). La dirección escolar. Postgrado/Master en dirección de centros para la innovación educativa. Barcelona: Universitat Autònoma de Barcelona.

Badia, J., \& Martínez, M. (2012). Protocol per a l'observació de contextos de lideratge per a l'aprenentatge. Internal document. Barcelona: Fundació Jaume Bofill.

Bolívar, A. (2004). La autonomía de los centros escolares. Revista de Educación, 333, 91-116.

Bolívar, A. (2012). Políticas actuales de mejora y liderazgo educativo. Málaga: Aljibe.

Bonal, X. et al. (2004). Politica educativa i igualtat d'oportunitats. Prioritats i propostes. Barcelona: Mediterrània.

Bonal, X., \& Verger, A. (2013). L'agenda de la politica educativa a Catalunya: una anàlisi de les opcions de govern (2011-2013). Barcelona: Fundación Jaume Bofill.

Consell Escolar de Catalunya (2003). Inmigració i educació. XIV Jornades de Consells Escolars de Comuntats Autònomes i de l'Estat. Retrieved (15/06/2014) from: http://www6.gencat.es/cec/01-2003.htm.

Departament d'Educació (2005). Pacte Nacional per a l'Educació. Generalitat de Catalunya.

Eurydice (2007). School autonomy in Europe: Policies and measures. Bruxelles: Eurydice.

Fullan, M. (2012). The change leader. Center for Development and Learning. Retrieved (15/06/2014) from: http://goo.gl/Hrtbcd. 
Gairín, J. (Coord.). (2005). La descentralización educativa: ¿una solución o un problema? Barcelona: Praxis.

Gómez-Dacal, G. (2013). Claves para la excelencia educativa. Organizaciones escolares unicas y excepcionales. Madrid: Wolters Kluwer.

Hallinger, P. (2011). Leadership for learning: Lessons from 40 years of empirical research. Journal of Educational Administration, 40(2), 125-142.

Hargreaves, A., \& Fink, D. (2008). El liderazgo sostenible. Siete principios para el liderazgo en centros educativos innovadores. Madrid: Morata.

Hargreaves, A., \& Fullan, M. (2012). Professional capital. Transforming teaching in every school. New York: Teachers College of Columbia University.

Leiva, V. (Coord.). (2014). Asesoramiento educativo. ¿Qué necesitan nuestras escuelas? Viña del Mar: Altazor.

MacBeath, J. (2012). Collaborate, innovate and lead: The future of the teaching profession. Debats d'Educació. Barcelona: Fundació Jaume Bofill.

Malpica, F. (2013). 8 ideas clave. Calidad de la práctica educativa. Referentes, indicadores y condiciones para mejorar la enseñanza-aprendizaje. Barcelona: Graó.

Maragall, E., \& Colomer, F. (2013). Escola nova, poble lliure: 1492 dies a educació. Disculpeu les molèsties. Barcelona: RBA La Magrana.

Marchesi, A., \& Martín, E. (Coords.) (2002). La evaluación: de la educación secundaria. Fotografía de una etapa polémica. Madrid: Ediciones SM.

Marsick, V. J. et al. (2013). Schools as learning communities. In A. R. Huang et al. (Eds.). Reshaping learning. New frontiers of educational research (pp. 71-88). New York: Springer.

Martínez, M., Badia, J., \& Jolonch, A. (2013). Lideratge per a l'aprenentatge. Estudis de cas a Catalunya. Barcelona: Fundació Jaume Bofill.

OECD (2011). School autonomy and accountability: Are they related to student performance? Pisa in Focus, 9.

Pont, B., Nusche, D., \& Moorman, H. (2008). Improving school leadership, Vol. 1: Policy and practice. Paris: OECD.

Quiroga, M. (Coord.). (2013). Crónicas de directores: cambio y liderazgo desde la zona de incomodidad. Valparaíso: Pontificia Universidad Católica de Valparaíso.

Salavert, R. (2013). Lideratge per a l'aprenentatge: fonaments teòrics. In M. Martínez, J. Badia, \& A. Jolonch (Coords.), Lideratge per a l'aprenentatge. Estudis de cas a Catalunya (pp. 31-54). Barcelona: Fundació Jaume Bofill.

Silva, J. M. (2010). Lideres e lideranças em escolas portuguesas. Protagonistas, prácticas e impactos. Vila Nova de Gaia: Fundacçao Manuel Leäo. 


\section{RiassunTO}

I processi di decentramento dell'istruzione sorgono, in molti casi, nell'ambito dello sviluppo dell'autonomia istituzionale. Di conseguenza viene richiesta una contestualizzazione delle attività di istruzione ed un maggiore coinvolgimento dei suoi principali protagonisti. L'autonomia delle scuole è stata sviluppa dal 1985, quando sono stati istituiti i consigli scolastici che hanno avuto il compito di selezionare presidi e dirigenti scolastici. Anche se sono continuati i cambiamenti legislativi, si sono verificati pochi progressi nell'ambito dell'autonomia didattica e lo sviluppo dell'autonomia organizzativa ed economico-amministrativa, nel contesto spagnolo, continua ad essere una sfida. Il modello istituito, che permette la gestione autonoma della Comunità, si è occupato della scelta dei presidi solo per un breve periodo. Anche se la Comunità Autonoma della Catalogna ha elaborato una proposta più professionale, che comprende la formazione preliminare e la presentazione di progetti di gestione, certamente continua ad esserci un malfunzionamento del sistema di istruzione e ciò è motivo di costante polemica. Questo testo esamina la nascita e lo sviluppo delle proposte che sono state fatte riguardo ai problemi di autonomia e gestione nel contesto spagnolo.

Parole chiave: Autonomia istituzionale, Decentramento, Gestione, Innovazione, Leadership. 